\title{
Evaluation of Fairness of Trademarks Royalty Prices in Transfer Pricing Transactions (Case Study of PT X Court Decisions)
}

\section{Evaluasi Kewajaran Harga Royalti Trademarks Dalam Transaksi Transfer Pricing (Studi Kasus Putusan Pengadilan PT X)}

\author{
Intan Puspanita ${ }^{1}$, Danny Septriadi ${ }^{2}$ \\ ${ }^{1}$ Universitas Sultan Ageng Tirtayasa \\ Email: intan.puspanita@untirta.ac.id \\ 2Universitas Indonesia \\ Email: dannyseprtiadi@gmail.com
}

\begin{abstract}
This study aims to analyze the arm's length price of transfer pricing transactions for parties conducting cross-border transactions as well as to see the basis and considerations of the panel of judges regarding royalty on trademark license for tax court decision disputes. The method used in this research is a qualitative approach by looking at the sources of books, documents, national and international journals, as well as laws related to the research topic of transfer pricing. The results of this study concluded that the beneficial owner of IP was Friesland Brands BV, therefore the economic ownership of the IP was Friesland Brands BV because it had developed and continued to develop royalties on the trademark of data, methods, processes, capabilities and expertise in connection with the milk-making activity. The Panel of Judges did not use the various meanings of a trademark to prove the existence of the trademark. The definition of a trademark that can be used by judges to prove the existence of a trademark is based on international and domestic provisions.
\end{abstract}

Keyword: arm's length price, tax dispute, trademarks

\begin{abstract}
ABSTRAK
Penelitian ini bertujuan untuk menganalisis harga wajar atas transaksi transfer pricing bagi pihakpihak yang melakukan transaksi lintas negara serta melihat dasar dan pertimbangan majelis hakim terkait royalty on trademark lisence atas sengketa putusan pengadilan pajak. Metode yang digunakan dalam penelitian ini yaitu menggunakan pendekatan kualitatif dengan melihat berbagai sumber antara lain yaitu buku-buku, dokumen, jurnal nasional dan internasional, serta undang-undang yang terkait dengan topik transfer pricing. Hasil penelitian ini memperoleh kesimpulan bahwa beneficial owner atas IP adalah Friesland Brands BV, oleh karena itu economic ownership atas IP tersebut adalah Friesland Brands BV karena telah mengembangkan dan melanjutkan untuk mengembangkan royalty on trademark tersebut atas data, metode, proses, kemampuan dan keahlian sehubungan dengan aktivitas pembuatan susu tersebut. Majelis Hakim tidak menggunakan berbagai pengertian merek dagang untuk melakukan pembuktian keberadaan merek dagang tersebut. Pengertian merek dagang yang dapat digunakan hakim untuk membuktikan keberadaan trademark (merek dagang) tersebut berdasarkan ketentuan internasional dan domestik.
\end{abstract}

Kata Kunci: harga wajar, sengketa pajak, trademarks 


\section{PENDAHULUAN}

Transaksi transfer pricing merupakan transaksi yang terkait dengan pihak-pihak yang memiliki hubungan istimewa atau pihak afiliasinya. Apabila terdapat hubungan istimewa, kemungkinan dapat terjadi penghasilan dilaporkan kurang dari semestinya ataupun pembebanan biaya melebihi dari yang seharusnya. Untuk menentukan nilai transaksi antara pihak-pihak yang memiliki hubungan istimewa maka kriteria yang dapat digunakan yaitu dengan prinsip harga wajar. Kesulitan dalam menerapkan prinsip kewajaran adalah apabila perusahaan afiliasi melakukan transaksi yang tidak dilakukan oleh perusahaan independen karena hanya sedikit atau tidak ada bukti langsung yang ditetapkan oleh perusahaan independen (paragraf 5.1.3 UN TP Manual, 2013).

Perhatian terhadap transaksi intangible property sangat diperlukan karena masih sulitnya menentukan nilai kewajaran dari transaski antara pihak-pihak yang memiliki hubungan istimewa. Menurut Markham (2005) sampai saat ini arm's length principle telah diterima secara umum sebagai cara terbaik untuk menghindari pajak berganda pada transaksi bisnis internasional dan merupakan suatu yang universal untuk transaksi aset berwujud, aset tidak berwujud, maupun transaksi jasa. Arm's length principle merupakan dasar yang digunakan untuk menangani masalah transfer pricing yang dialami oleh banyak negara di dunia (Chen, 2009). Secara konseptual, arm's length principle memanifestasikan harapan umum dari peraturan, praktek dan bagan persetujuan terhadap parameter dari yurisdiksi pajak dalam pengaturan internasional (Wilkie, 2012). Dalam prinsip arm's length principle, OECD memberlakukan perusahaan multinasional sebagai entitas terpisah, hal ini dimaksudkan untuk menghindari kemungkinan distorsi pendapatan dan kewajiban pajak dalam transaksi transfer pricing antara perusahaan afiliasi yang tidak mencerminkan harga pasar (Markham, 2005).

Pada dasarnya, arm's length principle diterapkan OECD yaitu untuk menghadapi masalah transfer pricing. Alasan utama mengapa OECD memilih metode ini adalah karena prinsip ini menempatkan perusahaan-perusahaan dari satu grup dalam kondisi yang sama dengan perusahaan yang independen sehingga menghilangkan faktor-faktor yang menguntungkan maupun yang merugikan (Surahmat, 2005). Arm's length principle tidak dapat direalisasikan pada harga transaksi independen, jika tidak terdapat harga yang sebanding di pasar bebas (Chen, 2009). Hal ini sejalan dengan pendapat Rachmanto Surahmat (2005) bahwa salah satu kesulitan dalam menerapkan arm's length principle adalah perusahaan-perusahaan yang mempunyai hubungan istimewa sering kali melakukan transaksi yang tidak dilakukan oleh pihak-pihak yang independen. Oleh karena itu arm's length principle harus ditentukan kembali dengan menggunakan simulasi tawar-menawar antar perusahaan afiliasi (Chen, 2009). OECD Guidelines menunjukkan dengan jelas bahwa analisis kesebandingan adalah inti dari arm's length principle. Oleh karena itu paragraf 1.7 OECD Guidelines 2010, mengatakan bahwa diperlukan suatu perbandingan antara kondisi yang dipengaruhi oleh hubungan istimewa dengan kondisi yang tidak dipengaruhi oleh hubungan istimewa atau kondisi yang independen.

Menurut OECD (2010) paragraf 1.2 OECD Guidelines, ketika perusahaan independen melakukan suatu transaksi maka kondisi hubungan komersial dan keuangan atas harga dari barang dan jasa yang ditransfer ditentukan oleh kekuatan pasar. Disisi lain, suatu kondisi spesial yang tercipta dalam transaksi afiliasi menunjukkan bahwa transaksi afiliasi tersebut tidak dipengaruhi oleh kekuatan pasar, melainkan terbentuk dari suatu kekuatan yang dikendalikan oleh tujuan bersama dari entitas-entitas dalam grup perusahaan multinasional tersebut (Darussalam, Septriadi dan Kristiaji, 2013).

Di Indonesia penerapan prinsip kewajaran dan kelaziman usaha dalam transaksi wajib pajak dengan pihak yang mempunyai hubungan istimewa diatur dalam PER-43/PJ/2010 (Direktorat Jenderal Pajak, 2010). Peraturan Direktorat Jenderal Pajak ini mengalami perubahan dalam beberapa pasalnya yang diatur dalam PER-32/PJ/2011 tanggal 11 November 2011. Dalam Pasal 17 PER-32/PJ/2011 mengatur untuk transaksi pemanfaatan harta tidak berwujud (intangibles) dengan pihak yang mempunyai hubungan istimewa. Intangible disini sebagaimana dimaksud dalam Pasal 17 ayat (3) PER-32/PJ/2011 yaitu meliputi trade intangibles dan marketing intangibles. Dalam pasal 17 ayat (7) PER-32/PJ/2011 pihak yang mempunyai hubungan istimewa dianggap memenuhi prinsip kewajaran dan kelaziman usaha sepanjang 
memenuhi ketentuan antara lain yaitu: transaksi pemanfaatan harta tidak berwujud benarbenar terjadi, adanya manfaat ekonomis dan komersial, dan transaksi tersebut mempunyai nilai yang sama dengan pihak-pihak yang tidak mempunyai hubungan istimewa yang mempunyai kondisi yang sebanding dengan menerapkan analisis kesebandingan dan menerapkan metode penentuan harga transfer yang tepat ke dalam transaksi (Direktorat Jenderal Pajak, 2011). Struktur perusahaan atas perusahaan-perusahaan yang melakukan transaski lintas negara dan besarnya koreksi Direktorat Jenderal Pajak menjadi latar belakang atas pemilihan kasus ini.

\section{METODE PENELITIAN}

Penelitian ini menggunakan pendekatan kualitatif. Pendekatan kualitatif tidak bertujuan untuk melakukan konfirmasi realitas, seperti dalam uji hipotesis tetapi justru menampakkan (atau membangun) realitas yang sebelumnya bersifat tacit, implisist, tersembunyi, menjadi nyata, eksplisit atau nampak (Irawan, 2006). Penelitian ini melakukan pendekatan kuliatatif studi literatur yaitu dengan melihat sumber buku-buku, dokumen, jurnal nasional dan internasional, serta undang-undang yang terkait dengan topik penelitian. Jurnal-jurnal yang ditelusuri yaitu berkaitan dengan transaksi transfer pricing, analisis kewajaran terkait putusan pengadilan pajak Nomor: Put.42729/PP/M.I/15/2013.

\section{HASIL DAN PEMBAHASAN}

Dalam menentukan harga wajar untuk aset tidak berwujud maka perlu didasarkan dari kedua presfektif yaitu pentransfer aset (transferor) dan pihak yang menerima pengalihan aset tersebut (transferee). Dari sisi transferor, prinsip kewajaran ditentukan berdasarkan harga wajar yang sebanding dengan harga yang ditetapkan oleh perusahaan independen sehingga bersedia mentransfer aset tidak berwujud yang sejenis. Sedangkan dari sisi transferee, harga wajar suatu transaksi ditentukan berdasarkan kesiapan perusahaan independen dalam membayar harga dalam jumlah yang sama dengan melihat nilai dan kegunaan dari aset tidak berwujud bagi bisnisnya. Pada umumnya transferee bersedia membayar biaya lisensi jika manfaat yang diharapkan dari penggunaan aset tidak berwujud tersebut dapat lebih memberi keuntungan dibandingkan menggunakan alternatif lain yang tersedia. Mengingat bahwa yang menggunakan lisensi (licensee) harus melakukan investasi dan akan mengeluarkan biaya, maka untuk menggunakan lisensi dilihat apakah perusahaan independen bersedia membayar biaya lisensi dari jumlah yang diberikan dengan mempertimbangkan manfaat yang diharapakan dan biaya yang dikeluarkan dari kemungkinan-kemungkinan yang akan terjadi pada investasi tersebut.

Dalam paragraf 6.15 OECD Guidelines (2010) maka analisis kewajaran penting diperlukan untuk memastikan bahwa perusahaan afiliasi tidak diwajibkan untuk membayar jumlah pembelian dan penggunaan dari aset tidak berwujud yang didasarkan pada tingkat tertinggi atau penggunaan paling produktif yang digunakan saat aset tidak memberikan kegunaan terhadap operasi bisnis perusahaan afiliasi. Hal ini menyoroti pentingnya melihat semua fakta dan keadaan yang menjadi pertimbangan dalam menentukan transaksi kesebandingan. Ketika royalti didasarkan pada output lisensi atau penjualan maka "royalty rate" tersebut bervariasi sesuai dengan omset pemegang lisensi, selain itu juga terdapat fakta dan keadaan yang dapat berubah (misalnya desain baru, peningkatan iklan atas merek dagang tersebut oleh pemilik) dapat menyebabkan revisi dari kondisi remunerasi (paragraf 6.16 OECD Guidelines, 2010). Dalam paragraf 7.5 OECD Guidelines, terdapat dua isu dalam menganilisis transaksi transfer pricing yang terjadi pada perusahaan multinasional. Isu yang pertama adalah apakah jasa tersebut benar-benar diberikan dan masalah lain yaitu apakah biaya yang dikeluarkan untuk pemberian jasa tersebut telah dilakukan sesuai prinsip kewajaran (arm's length principle). Berikut ini akan dijabarkan dasar koreksi pemeriksa terkait koreksi biaya Royalty on Trademark Lisences: 
Tabel 1

Analisis Argumentasi terkait Royalty on Trademark Lisences

\begin{tabular}{|c|c|c|}
\hline & Pemeriksa Pajak & Wajib Pajak \\
\hline ARGUMENTASI & $\begin{array}{l}\text { 1. Pada saat pemeriksaan, pemohon } \\
\text { banding tidak dapat menyediakan } \\
\text { data dan dokumen terkait yang } \\
\text { diperlukan Pemeriksa untuk menguji } \\
\text { apakah pembebanan royalty on } \\
\text { trademark telah sesuai prinsip } \\
\text { kewajaran. } \\
\text { 2. Tidak ada penjelasan atau data yang } \\
\text { dapat membuktikan kepemilikan } \\
\text { trademark baik secara legal maupun } \\
\text { ekonomi, sehubungan dengan usaha } \\
\text { Wajib Pajak terkait dengan aktivitas } \\
\text { pembuatan susu dan pemasarannya } \\
\text { sebagaimana yang tercantum dalam } \\
\text { kontrak perjanjian pemohon banding } \\
\text { dengan Friesland Brands BV. } \\
\text { 3. Pengujian juga dilakukan terhadap } \\
\text { eksistensi, manfaat, duplikasi serta } \\
\text { dokumentasi dan penilaian terhadap } \\
\text { royalty on trademark tersebut. }\end{array}$ & $\begin{array}{l}\text { 1. Wajib Pajak tidak memenuhi } \\
\text { permintaan dokumen oleh DJP karena } \\
\text { tahun } 2007 \text { belum ada peraturan yang } \\
\text { detail tentang TP documentation. } \\
\text { 2. Menurut WP apabila biaya royalti } \\
\text { dikecualikan dari biaya yang menjadi } \\
\text { pengurang pendapatan maka akan } \\
\text { terjadi pengenaan pajak berganda yang } \\
\text { tidak sesuai dengan P3B antara } \\
\text { Indonesia dengan Belanda. } \\
\text { 3. Telah dilakukan uji nilai pasar wajar } \\
\text { atas presentase nilai royalti antara } \\
\text { Frieslands Brands BV dengan PT XXX } \\
\text { sehubungan perjanjian know-how. } \\
\text { 4. Terdapat eksistensi dan pemanfaatan } \\
\text { atas trademark dibutuhkan untuk } \\
\text { mendukung proses pembuatan produk } \\
\text { susu tersebut termasuk pemasaran, } \\
\text { Supply Chain Management, SDM, } \\
\text { Keuangan, IT dan sebagainya. } \\
\text { 5. Tidak ada duplikasi atas jasa yang } \\
\text { dilakukan. } \\
\text { Terkait dengan penilaian, maka } \\
\text { pengguna lisensi (pemohon banding) } \\
\text { akan membayar kepada pemilik lisensi } \\
\text { dengan nilai total 2\% dari total } \\
\text { penjualan bersih atas semua produk } \\
\text { untuk setiap tahun. }\end{array}$ \\
\hline
\end{tabular}

Masalah kepemilikan aset tidak berwujud dapat memiliki efek yang signifikan pada bagaimana peraturan transfer pricing yang diterapkan di berbagai yurisdiksi pajak dan seringkali kepemilikan menyiratkan tidak hanya hak untuk pendapatan yang dihasilkan oleh eksploitasi aset tidak berwujud yang bersangkutan, tetapi juga pajak dan pengalihan konsekuensi harga yang terkait (Przysuski, Lalapet dan Swaneveld, 2004).

Untuk menganalisis transaksi transfer pricing aset tidak berwujud maka perlu untuk mengidentifikasi pemilik dan/atau penerima manfaat dari aset tidak berwujud tersebut, karena ada perusahaan yang merupakan pemilik dengan paten atau merek dagang yang terdaftar dan dilain pihak ada perusahaan yang memberikan kontribusi pada pencipataan atau pengembangan intangibles (Irina, 2014). Oleh karena itu perlu dibedakan antara kepemilikan secara hukum dan kepemilikan secara ekonomi. Menurut Irina (2014) economic owner bisa dikatakan sebagai investor dan legal owner adalah orang atau perusahaan yang dapat memiliki paten atau merek dagang dan mendapatkan hak melalui kontrak.

Terkait dengan pembayaran royalty on trademark lisences pihak pemeriksa telah melakukan koreksi atas kewajaran transaksi yang dilakukan oleh Wajib Pajak. Uji kewajaran dilakukan untuk melihat siapa pemilik intangible property dan melihat apakah umur intangible property masih commercially available dan bagaimana cara mengembangkan intangible property tersebut. Dalam menilai suatu intangible property, maka perlu diketahui prinsip kewajaran dan metode yang digunakan untuk menilai royalty yang dibayarkan kepada pihak afiliasinya apakah sudah sesuai dengan prinsip kewajaran (arm's length principle). Dalam paragraf 6.14 OECD Guidelines $\left(2010_{\mathrm{b}}\right.$ ) maka dalam menentukan harga wajar untuk aset tidak berwujud perlu didasarkan dari kedua presfektif yaitu pentransfer aset (transferor) dan pihak yang menerima pengalihan aset tersebut (transferee). Dari sisi transferor, prinsip kewajaran ditentukan berdasarkan harga wajar yang sebanding dengan harga yang ditetapkan oleh perusahaan independen sehingga bersedia mentransfer aset tidak berwujud yang sejenis. Sedangkan dari 
sisi transferee, harga wajar suatu transaksi ditentukan berdasarkan kesiapan perusahaan independen dalam membayar harga dalam jumlah yang sama dengan melihat nilai dan kegunaan dari aset tidak berwujud bagi bisnisnya.

Pemeriksa pajak melakukan koreksi positif atas biaya royalty on trademark lisences sebesar Rp94.172.423.297 yang merupakan koreksi akibat transfer pricing yang terjadi dengan perusahaan yang memiliki hubungan istimewa yaitu Friesland Brands BV yang bertempat kedudukan di negara Belanda. Hubungan istmewa terjadi karena antara pemohon banding dan Friesland Brands BV memiliki penguasaan yang sama melalui manajemen dan penggunaan teknologi sesuai dengan pasal 18 ayat (4) huruf b Undang-undang Pajak Penghasilan. Dengan demikian, Pemeriksa menggunakan aturan sesuai dengan P3B antara Indonesia dengan Belanda atas transaksi ini, dan juga merujuk pada OECD Transfer Pricing Guidelines. Telah dibuktikan bahwa Pemohon Banding memiliki hubungan istimewa dengan Friesland Brands BV.

Menurut Pemeriksa, dalam OECD Guidelines paragraf 6.3, 6.6, dan 6.10 maka untuk pengakuan suatu kepemilikan intangible property, perlu diketahui siapa pemilik intangible property tersebut. Dalam paragraf 6.3 maka aset tidak berwujud dibedakan menjadi dua yaitu trade intangible dan marketing intangible. Untuk trade intangible atau marketing intangible maka harus ada kepedulian untuk menentukan keberadaaanya, karena tidak semua pengeluaran penelitian dan pengembangan menghasilkan trade intangible dan tidak semua aktivitas pemasaran menghasilkan marketing intangible. Hal ini bisa sulit untuk mengevaluasi sejauh mana pengeluaran tertentu telah berhasil menghasilkan aset bisnis dan menghitung dampak ekonomi dari aset tersebut untuk tahun tertentu (paragraf 6.6 OECD Guidelines, 2010). Dalam paragraf 6.10 OECD Guidelines (2010) maka kepemilikan merek dagang biasanya akan diberikan kepada satu orang, misalnya: secara hukum perusahaan independen.

Kepemilikan intangible asset dibedakan menjadi kepemilikan secara ekonomi dan kepemilikan secara hukum. Kepemilikan secara hukum dikaitkan dengan titel hukum yang dapat diberikan atas aset tersebut. Pada umumnya, hal ini berhubungan dengan perlindungan hukum yang diberikan atas dasar hukum kekayaan intelektual. Misalkan hak paten, hak cipta, merek dagang terdaftar, dan lain-lain. Perlu diperhatikan bahwa tidak semua jenis aset tidak berwujud bisa dilindungi secara hukum, misalkan know-how dari pengalaman. Konsep kepemilikan secara ekonomi mengakui pemilik dari suatu aset tidak berwujud sebagai pihak yang telah menanggung sebagian besar biaya-biaya dan risiko terkait dengan pengembangan dan/atau pemeliharaan nilai daripada aset tidak berwujud tersebut Darussalam, Septriadi dan Kristiaji (2013).

Identifikasi kepemilikan legal dapat ditentukan dari analisis syarat dan ketentuan perjanjian, registrasi, perjanjian lisensi, dan kontrak lain yang relevan. Sedangkan kepemilikan ekonomi dapat dilihat dari perusahaan yang secara nyata menanggung biaya dan risiko terkait pengembangan trademark tersebut. Dalam perjanjian lisensi merek antara Friesland Brands BV dengan PT XXX (Pemohon Banding), bahwa merek dagang sehubungan dengan materi hak cipta, logo, slogan, desain label dan kemasan (secara kolektif disebut "Merek Dagang").

Kepemilikan ini dapat dilihat dari dokumen perjanjian lisensi antara PT XXX dengan Friensland Brands BV. Kepemilikan legal dikaitkan dengan titel hukum pada intangible tersebut dan kepemilikan ekonomi dikaitkan dengan pihak yang meanggung biaya dan risiko atas pengembangan intangibles. Berdasarkan paragraf 66 OECD Discussion Draft (2013) dalam melakukan analisis kepemilikan aset tidak berwujud dapat dilakukan dengan (1) identifikasi kepemilikan legal dari aset tidak berwujud tersebut; (2) mengidentifikasi pihak yang yang melakukan fungsi aset, dan risko biaya yang ditanggung dengan menggunakan analisis fungsional; dan (3) memastikan konsistensi antara perilaku para pihak dan ketentuan peraturan hukum yang relevan mengenai kepemilikan intangibles melalui analisis fungsional yang rinci. Dalam analisis fungsi, pemeriksa pajak diharapkan memiliki pemahaman yang baik tentang usaha Wajib Pajak. Dalam melakukan uji kepemilikan maka pemeriksa (DJP) dapat melihat peraturan negara lain (Grop, 2011).

Menurut pemeriksa, dalam mengetahui umur suatu intangible property, maka perlu diketahui siklus produk agar dapat diketahui intangible property tersebut masih commercially available atau tidak. Hal ini tercakup dalam OECD TP Guidelines paragraf 6.7, 6.12, dan 6.16. Intangible property juga perlu diketahui siapa dan bagaimana cara mengembangkannya, seperti 
yang tercakup dalam OECD TP Guidelines paragraf 6.9, 6.12, 6.21, 6.27, 6.38. Dalam melakukan pemeriksaan, maka Pemeriksa harus melihat kontrak perjanjian untuk dapat ditentukan siapa pemilik legal dan pemilik ekonomi dari trademark tersebut. Pemeriksa tidak dapat menggunakan kata-kata di dalam perjanjian trademark license agreement sebagai bukti. Pemeriksa harus melakukan pemeriksaaan untuk tahun-tahun pajak sebelum dan setelah pemeriksaan untuk mendapatkan informasi apakah transaksi pembayaran royalti telah dilakukan secara wajar. Hal ini dibuktikan bahwa untuk tahun pajak 2005 dan 2008, pihak Pemeriksa di KPP LTO telah menyetujui atas kewajaran pembebanan biaya royalti trademark. Sesuai SE-50/PJ/2013, terdapat beberapa langkah yang dapat digunakan oleh pemeriksa untuk mengidentifikasi keberadaan trademark. Merek dagang merupakan kategori dari marketing intangible dan untuk mengidentifikasi marketing intangibles, beberapa teknik yang dapat membantu meliputi diskusi dengan pihak pemasaran atau penjualan yang bertanggung jawab pada lini produk dan diskusi dengan pakar industri yang secara rutin mempelajari produk dan pasarnya (Wright, 1994). Berikut ditampilkan analisis bukti terkait royalty on trademark lisences:

Tabel 2

Analisis Bukti terkait Royalty on Trademark Lisences

Pemeriksa Pajak

BUKTI 1. Dalam proses pemeriksaan, Pemeriksa telah melakukan permintaan data, tetapi Wajib Pajak tidak dapat menyediakan data dan dokumen terkait yang diperlukan oleh Pemeriksa. Permintaan data dilakukan melalui:

- S11106/WPJ.19/KP.0205/200 8 tanggal 29 Juli 2008 tentang permintaan dokumen/data; S-

12258/WPJ.19/KP.0205/2008

tanggal 18 Agustus 2008 tentang Peringatan I;

S-

17581/WPJ.19/KP.0205/2008

tanggal 18 November 2008 tentang Peringatan II;

- S-2069/WPJ.19/KP.0205/2009 tanggal 02 Maret 2009 tentang Permintaan Data Hubungan Istimewa

2. Terkait dengan Eksistensi dan Manfaat, pemeriksa hanya menerima data berupa trademark lisence agreement sehingga belum bisa menunjukkan apakah hal-hal yang diatur dalam perjanjian tersebut dilaksakan/terjadi.
1. Untuk memenuhi permintaan data/dokumen dari DJP maka Wajib Pajak membuat TP documentation berupa Comparable Research Study dari pihak independen dengan metode CUP dan menyerahkan dokumen koreksi biaya royalti terutama TP documentation pada tanggal 24 Agustus 2009.

2. WP telah melampirkan tambahan data berupa Trademark Registration di Indonesia dan draft Royalty Comparable Search for Friesland Foods of Ernst \& Young (EY), Netherlands.

3. Untuk tahun pajak 2005 \& 2008, pihak pemeriksa di KPP LTO 2 telah menyetujui atas kewajaran pembebanan biaya royalti on trademark Pemohon Banding.

4. E\&Y, Netherlands dan PWC, Netherlands telah melakukan penelitian database untuk membandingkan perjanjian lisensi antara perusahaan yang independen. Dari kedua penelitian database di atas, maka angka 2\% untuk lisensi trademark yang dibebankan oleh Friesland Brands BV adalah konsisten dengan nilai transaksi wajar.

5. Terkait eksistensi maka:

Berdasarkan perjanjian trademark lisence agreement antara Friesland BV dengan pemohon banding pada tanggal 3 Juli 2003, maka benefecial owner atas royalty sehubungan dengan produk bubuk (powderlike products), susu kental manis (sweetened condensed milk) dan segala jenis susu cair dan produk susu adalah Friesland Brands BV, selanjutnya merek atas produk tersebut terdapat di Lampiran I perjanjian tersebut.

6. Berdasarkan trademark license agreement antara Friesland Brands BV dengan PT XXX maka tanggal 3 Juli 2003 disebutkan bahwa pemilik lisensi merek Friesland Brands BV setuju memberikan memberikan ijin penggunaan merek dan pengguna lisensi merek (Pemohon Banding) setuju untuk menerima hak khusus penggunaan merek selama jangka waktu perjanjian tersebut dalam wilayah Indonesia. 
Tabel 3

Hal-hal yang Perlu Dipertimbangkan terkait Royalty on Trademark Lisence

\begin{tabular}{|c|c|c|}
\hline & $\begin{array}{r}\text { Pemeriksa Pajak } \\
\end{array}$ & Wajib Pajak \\
\hline $\begin{array}{l}\text { PENDAPAT } \\
\text { PENELITIAN }\end{array}$ & $\begin{array}{l}\text { 1. Pemeriksa harus melihat kontrak perjanjian } \\
\text { untuk dapat ditentukan siapa pemilik legal dan } \\
\text { pemilik ekonomi dari trademark tersebut. } \\
\text { 2. Pemeriksa tidak dapat menggunakan kata-kata } \\
\text { di dalam perjanjian trademark license } \\
\text { agreement sebagai bukti. } \\
\text { 3. Pemeriksa harus melakukan pemeriksaaan } \\
\text { untuk tahun-tahun pajak sebelum dan setelah } \\
\text { pemeriksaan untuk mendapatkan informasi } \\
\text { apakah transaksi pembayaran royalti telah } \\
\text { dilakukan secara wajar. Hal ini dibuktikan } \\
\text { bahwa untuk tahun pajak 2005 dan 2008, } \\
\text { pihak Pemeriksa di KPP LTO telah menyetujui } \\
\text { atas kewajaran pembebanan biaya royalti } \\
\text { trademark. } \\
\text { Sesuai SE-50/PJ/2013, terdapat beberapa } \\
\text { langkah yang dapat digunakan oleh pemeriksa } \\
\text { untuk mengidentifikasi keberadaan trademark. } \\
\text { 5. Pemeriksa dapat meminta dokumen-dokumen } \\
\text { yang digunakan dalam pemeriksaan seperti } \\
\text { yang tercantum dalam KEP-01/PJ.7/1993 yang } \\
\text { dapat dikembangkan sebagai dasar } \\
\text { pembuktian dalam pemeriksaan. } \\
\text { 6elihat bagaimana otoritas perpajakan negara } \\
\text { lain membuktikan kepemilikan secara legal } \\
\text { dan ekonomi: } \\
\text { a. Jepang: Pihak yang menanggung biaya, } \\
\text { risiko dan melakukan fungsi-fungsi yang } \\
\text { terkait dengan pengembangan dan } \\
\text { pemeliharaan IP dapat dianggap pemilik IP } \\
\text { untuk tujuan transfer pricing. } \\
\text { b. Belanda: Pemilik legal yaitu yaitu } \\
\text { perusahaan yang terdaftar sebagai pemilik } \\
\text { sah dari IP di bawah hukum kekayaan } \\
\text { intelektual sedangkan kepemilikan } \\
\text { ekonomi mengacu pada perusahaan yang } \\
\text { melakukan fungsi-fungsi, menggunakan } \\
\text { aset dan mengasumsikan risiko terhadap } \\
\text { IP tersebut. }\end{array}$ & 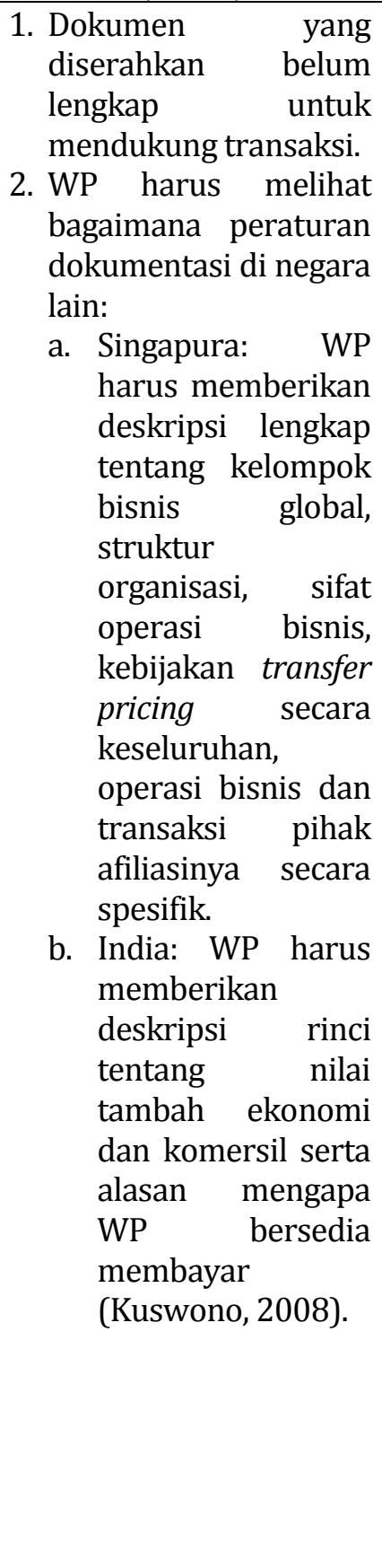 \\
\hline
\end{tabular}

PT XXX tidak setuju dengan pendapat Terbanding yang mempertahankan koreksi terhadap pembayaran royalty on trademark lisences kepada Friesland Brands BV karena menurut PT XXX perlakuan terhadap royalty on trademark lisences sama seperti trademark dan lisensi sebagai biaya yang tidak dapat dibiayakan adalah bertentangan dengan Pasal 6 ayat (1) Undang-undang Pajak Penghasilan, yang menyebutkan bahwa royalti termasuk biaya untuk mendapatkan, menagih dan memelihara penghasilan. Selain itu juga, karena pembayaran royalti dilakukan kepada Friesland Brands BV yang berkedudukan di Belanda, maka menurut PT XXX (Pemohon Banding) perlakuan pajak seharusnya mengacu pada P3B antara Indonesia dan Belanda.

Bahwa pasal 12 ayat (1) P3B antara Indonesia dan Belanda menyebutkan: "Hak pajak atas royalty dibagi anatara dua negara, yaitu Indonesia (source state) dan Belanda (resident state)". Maka menurut PT XXX, apabila biaya royalti dikecualikan dari biaya yang menjadi pengurang 
pendapatan oleh Pemeriksa (Terbanding) akan terjadi pengenaan pajak berganda yang tidak sesuai dengan pasal 12 ayat (1) P3B Indonesia dan Belanda. Dari alasan banding tersebut maka diproses sesuai dengan ketentuan Perundang-undangan Nomor 14 tahun 2002 tentang pengadilan pajak. Adapun dasar dan pertimbangan majelis hakim ditunjukkan tabel berikut:

\section{Tabel 4}

Dasar dan Pertimbangan Majelis Hakim terkait Royalty on Trademarks Lisences

\begin{tabular}{|c|c|}
\hline Putusan Majelis Hakim & Komentar Penelitian \\
\hline $\begin{array}{l}\text { a. Dalam perkara banding ini Terbanding } \\
\text { tidak menentukan jumlah wajar } \\
\text { sebagaimana dimaksud Pasal } 9 \text { ayat (1) } \\
\text { huruf f Undang-undang Pajak } \\
\text { Penghasilan. } \\
\text { b. Berdasarkan proses pemeriksaan lebih } \\
\text { bayar terhadap PT XXX tahun } 2005 \text { dan } \\
2008 \text { di KPP LTO, diketahui pemeriksa } \\
\text { telah menyetujui pembebanan biaya } \\
\text { royalty on trademark PT XXX. } \\
\text { c. PT XXX mempunyai trademark license } \\
\text { agrrement yang berisi persetujuan } \\
\text { untuk membayar royalti sebesar } 2 \% \\
\text { dari penjualan bersih. Berdasarkan hasil } \\
\text { penelitian E\&Y Netherlands angka } 2 \% \\
\text { adalah untuk Trademark Lisence adalah } \\
\text { konsisten dengan nilai transaksi wajar. } \\
\text { Selain itu juga, PT XXX telah } \\
\text { melampirkan dokumen berupa } \\
\text { Trademark Registration yang } \\
\text { membuktikan eksistensi secara legal } \\
\text { bahwa Benefecial Owner atas royalty } \\
\text { adalah Frieslands Brands BV. }\end{array}$ & $\begin{array}{l}\text { - Berdasarkan UU PPh Pasal } 18 \text { ayat (3) maka DJP } \\
\text { berwenang untuk menentukan kembali besarnya } \\
\text { penghasilan dan pengurangan serta menentukan } \\
\text { utang sebagai modal untuk menghitung besarnya } \\
\text { Penghasilan Kena Pajak bagi Wajib Pajak yang } \\
\text { mempunyai hubungan istimewa dengan Wajib } \\
\text { Pajak lainnya sesuai dengan kewajaran dan } \\
\text { kelaziman usaha yang tidak dipengaruhi oleh } \\
\text { hubungan istimewa. Sesuai pasal ini, seharusnya } \\
\text { DJP menentukan kembali jumlah wajar } \\
\text { pembayaran royalty on trademark tersebut } \\
\text { melalui beberapa metode misalnya metode } \\
\text { perbandingan dengan pihak independen. } \\
\text { - Karena tahun pajak } 2005 \text { dan 2008, kewajaran } \\
\text { dalam pembebanan biaya royalti oleh wajib pajak } \\
\text { telah disetujui oleh pemeriksa, maka majelis } \\
\text { hakim sesuai kewenangannya perlu memeriksa } \\
\text { apakah terdapat pembetulan yang dilakukan oleh } \\
\text { PT XXX terkait dengan dokumentasi ataupun } \\
\text { bukti-bukti lainnya yang mendukung nilai } \\
\text { kewajaran tersebut, karena berbeda dengan } \\
\text { tahun pajak } 2007 \text { yang dilakukan koreksi oleh } \\
\text { DJP } \\
\text { - Dengan adanya trademark registration maka } \\
\text { dapat diketahui siapa pemilik atas intangible } \\
\text { tersebut. }\end{array}$ \\
\hline
\end{tabular}

Terkait dengan pengujian kewajaran yang dilakukan oleh Pemeriksa atas kewajaran transaksi yang memperhatikan unsur kepemilikan, siklus produk dan kewajaran atas pembayaran royalti atas trademark (merek dagang), berdasarkan surat penjelasan atas surat permohonan oleh tim pembahas tingkat kanwil dengan surat Nomor: 271/TAX/FFI/IV/09 tanggal 13 April 2009, maka pemohon banding telah melampirkan dokumen yang menyatakan bahwa benefecial owner atas royalty sehubungan dengan produk bubuk, susu kental manis, dan segala jenis susu cair dan produk susu adalah Friesland Brands BV.

Dalam melakukan pembuktiannya, majelis hakim hanya melihat berdasarkan dokumen yang diberikan oleh pemohon banding yaitu berupa trademark lisence agreement. Majelis Hakim tidak menggunakan berbagai pengertian merek dagang untuk melakukan pembuktian keberadaan merek dagang tersebut. Pengertian merek dagang yang dapat digunakan hakim untuk membuktikan keberadaan trademark (merek dagang) tersebut berdasarkan ketentuan internasional dan domestik antara lain yaitu pengertian merek dagang berdasarkan Agreement on Trade-Related Aspects of Intellectual Rights (TRIPS) dari World Intellectual Property Organization (WIPO), OECD Transfer Pricing Guidelines, dan Undang-undang Nomor 15 Tahun 2001 tentang Merek (Tobing, 2013). 


\section{KESIMPULAN}

Beneficial owner atas IP adalah Friesland Brands BV, oleh karena itu economic ownership atas IP tersebut adalah Friesland Brands BV karena telah mengembangkan dan melanjutkan untuk mengembangkan royalty on trademark tersebut atas data, metode, proses, kemampuan dan keahlian sehubungan dengan aktivitas pembuatan susu tersebut. Majelis Hakim tidak menggunakan berbagai pengertian merek dagang untuk melakukan pembuktian keberadaan merek dagang tersebut. Pengertian merek dagang yang dapat digunakan hakim untuk membuktikan keberadaan trademark (merek dagang) tersebut berdasarkan ketentuan internasional dan domestik antara lain yaitu pengertian merek dagang berdasarkan Agreement on Trade-Related Aspects of Intellectual Rights (TRIPS) dari World Intellectual Property Organization (WIPO), OECD Transfer Pricing Guidelines, dan Undang-Undang Nomor 15 Tahun 2001 tentang Merek. Penelitian ini menyarankan agar terkait dengan royalty on trademark maka dapat melihat kepemilikan legal dan ekonomi di negara lain seperti di Jepang dan Belanda. Majelis Hakim dapat melakukan penelusuran lebih lanjut untuk memastikan transaksi royalty trademark tersebut sudah sesuai dengan arm's length principle. Agar putusan yang di ambil lebih adil dan berkualiatas maka dalam pengambilan keputusannya Majelis Hakim dapat melihat dan mempertimbangkan pendapat para ahli serta mengacu pada prinsip substance over form.

\section{DAFTAR PUSTAKA}

Chen, X. (2009). Behavioral Game Split: A New Perspective on the Arm 's-Length Principle. Tax Management Transfer Pricing Report, 17(19), 751-754.

Darussalam, Septriadi, D., \& Kristiaji, B. B. (2013). Transfer Pricing, Ide, Strategi, dan Panduan Praktis Dalam Perspektif Pajak Internasional. Jakarta: Danny Darussalam Tax Center.

Direktorat Jenderal Pajak. (1993). Surat Edaran Direktorat Jenderal Pajak SE-04/PJ.7/1993 tanggal 9 Maret 1993 yang Mengatur tentang Petunjuk Penanganan Kasus-Kasus Transfer Pricing (Seri TP-1)

Direktorat Jenderal Pajak. (2010). Peraturan Direktur Jenderal Pajak Nomor PER-43/PJ/2010 tentang Penerapan Prinsip Kewajaran dan Kelaziman Usaha dalam Transaksi Antara Wajib Pajak dengan Pihak Yang Mempunyai Hubungan Istimewa.

Direktorat Jenderal Pajak. (2011). Peraturan Direktur Jenderal Pajak Nomor PER-32/PJ/2011 tentang Perubahan Atas Peraturan Jenderal Pajak Nomor PER-43/PJ/2010 tentang Penerpaan Prinsip Kewajaran dan Kelaziman Usaha dalam Transaksi Antara Wajib Pajak dengan Pihak Yang Mempunyai Hubungan Istimewa.

Direktorat Jenderal Pajak. (2013). Surat Edaran Direktur Jenderal Pajak Nomor SE-50/PJ/2013 tentang Petunjuk Teknis Pemeriksaan Terhadap Wajib Pajak Yang Mempunyai Hubungan Istimewa.

Gorp, M.V. (2011). The Definition, Ownership and Transfer Issues Around Intangible Property Under The OECD Transfer Pricing Guidelines. Belanda: University of Tilburg.

Irina, Timoshenko. (2014). Definition and Valuation of Intangible Assets for Internastional Transfer Pricing Purposes. Swedia: Lund University.

Markham, M. (2005). The Transfer Pricing of Intangible. The Hague, Netherlands: Kluwer Law International.

OECD. (2010). OECD Transfer Pricing Guidelines for Multinational Enterprises and Tax Administrations. Paris: OECD Publishing.

OECD. (2013). Revised Discussion Draft on Transfer Pricing Aspect of Intangibles. Paris: OECD Publishing.

Przysuski, B. M., Lalapet, S., \& Swaneveld, H. (2004). Transfer Pricing of Intangible Property Part I : A Canadian-US Comparison. 10-19.

Surahmat, R. (2005). Persetujuan Penghindaran Pajak Berganda. Jakarta: Gramedia Pustaka Utama. 
Tobing, C.G. (2013). Penemuan Hukum Dalam Sengketa Perpajakan. Inside Tax, Edisi 16, JuliAgustus 2013.

United Nations Department of Economic and Social Affairs. (2013). United Nations: Practical Manual on Transfer Pricing for Developing Countries. New York: United Nations.

Wilkie, J. S. (2012). Reflecting on the "Arm's Length Principle": What is the "Principle"? Where Next?. Dalam Fundamental of International Transfer Pricing in Law and Economics, ed W. Schon \& K.A.Konrad. Verlag Berlin Heidelberg: Springer.

Wright, D. R. (1994). Intangibles and Transfer Pricing. International Transfer Pricing Journal, Volume 1, No.2. Published by International Bureau of Fiscal Documentation, Amsterdam. 